\title{
Dynamics of Global Coastline: An Exposition of Erosional and Depositional Landforms Along The Komenda Coastline in The Central Coastal Plains of Ghana
}

\author{
Kofi Adu-Boahen, Ishmael Yaw Dadson and Samuel Agyekum
}

\section{ABSTRACT}

The coast is a dynamic region where various processes with their origin from the land, atmosphere and sea interact. The interactional nature of these processes gives rise to one of the most spectacular forms along coastlines and these are coastal landforms. However, there has not been much research that unearths and describes the coastal landforms caused by deposition and erosion along the about $1 \mathrm{~km}$ stretch of the Komenda Ghana coastline. The study is an exposition of the coastal landforms caused by both deposition and erosion along the coastline. The study thrived on a descriptive research design coupled with observations, measurements and photographic presentation. The study revealed diverse coastal erosional landforms along the Komenda shoreline which encapsulate caves, geo, a blowhole, a stack and stumps while the only depositional landforms found were rocky and sandy beaches. Also, the study revealed the massive operation of sub-aerial processes such as weathering and mass wasting as the main forces operating along the shoreline. The study recommends increased research along the area to ensure a better understanding of its climatic, hydrodynamical, geological and geomorphological conditions which will provide a more and comprehensive understanding of coastal landforms and the factors shaping the coastline at every point in time. The study area has high nature conservation and recreational value. Therefore, it is crucial to sustainably monitor and to improve the planning processes in these vulnerable landscapes.

Keywords: Coastline, Depositional, Erosional, Geomorphological, Sub-aerial processes.

\section{INTRODUCTION}

The diversity of coastal landscape depends mainly on the variation of geological features (especially deposits), climate and hydrological conditions (distance from sea), the development stages of ecosystems and the influence of human activity [1]. Coasts are ubiquitous to all the seven continents, most especially to countries that lie at their fringes. About a billion of the world's population resides within 100 kilometers of the coastline due to coastal resources [2]. For this reason, the coast has greatly been of interest to those that go down there for fishing and several others whose shelter and economic activities are dependent on coastal resources. However, the scientific study of coasts has become the preserve of a very few whose field of study is a clear manifestation of a considerable overlap of interest between them, of which some are the coastal geomorphologist, sand sedimentologists, coastal oceanographers and coastal engineers in the study of waves
Published Online: July 29,2020

ISSN: $2684-446 \mathrm{X}$

DOI :10.24018/ejgeo.2020.1.4.30

\section{K. Adu-Boahen*}

University of Education, Winneba Faculty of Social Science Education, Department of Geography Education, Winneba, Ghana.

(E-mail: kadu-boahen@uew.edu.gh)

\section{Y. Dadson}

University of Education, Winneba, Faculty of Social science Education, Department of Geography Education, Winneba, Ghana.

(E-mail: dadsonyaw@gmail.com)

\section{S. Agyekum}

University of Education, Winneba, Faculty of Social Science Education, Department of Geography Education, University of Education, Winneba. (E-mail: agyekumsamuel11@gmail.com)

*Corresponding Author and currents, and coastal erosion and deposition [3]. The earth subsystems imply a flow of energy from one component to another [4]. This is revealed as 'dominoeffect'. In other words, there exists a synergistic relationship between components of the earth where the process of one system initiates another. One that is of much interest to Coastal geomorphologists is the relationship between the atmosphere, ocean and the land surface (Coast). At the coast is the interplay of diverse earth processes originating from the atmosphere, the land surface, and the ocean. Processes operating in all three of these systems are responsible for shaping the coastal zone, and the interaction between the three different sets of processes makes the coastal zone an extremely dynamic one [3]. Reference [5] also emphasized that the coastlines are dynamic because of tidal forces and other coastal processes, therefore, it is difficult to determine coastlines hence, the term "coastal zone" best describes the coast, coastline or shoreline. As a result of the dynamism, coastal morphologies are relentlessly buffeted by processes such as wave action, 
climatic and as well as anthropogenic actions that culminate into different coastal geomorphic process regimes [6]. Also, this shoreline morphological change is assisted considerably by the geology, geomorphology, bathymetry, orientation of the shoreline and the level of human interference [7]. Various researchers have attempted to categorize the forces operating along the coast. Reference [8] averred that waves, nearshore currents, tsunamis are some of the forces that affect a coastline. Hugget furthered his argument by classifying the forces into degradational and aggradational processes. Degradational activities are for example weathering and wave action. Inductively, sub-aerial processes lead to degradation in the opinion of [8]. In mechanical weathering, water gets into the cracks of rocks and gets it wet and dries up when temperature rises; the alternate wetting and drying of rocks causes expansion and contracting respectively. The authors [9] asserted that this action is predominant along the coast of West Africa which Ghana is no exception. Chemically, rainwater combines with iron-laden rock and dissolves it through the process of Oxidation [9]. Aggradational activities however encapsulate biological activities of which some marine organisms build, and some help to build, particular coastal landforms. For instance, Corals and other carbonate-secreting organisms make coral reefs, which can be spectacularly large [8]. Reference [10] accounts that geomorphic processes along the coast do not operate in isolation but in combination. Hence, [10] espoused that waves and currents of the sea play the dominant role [11], but coastal forms are also shaped by fluvial processes, mass movements, and wind action. It must be emphasized that waves are the dominant factors that affect the coastline, [8]-[10] believes that waves and subaerial processes (temperature, rainfall and wind) are the factors that possibly shapes a coastline. Wind is sometimes considered independent or stated as part of the waves. While some regimes exhibit a high rate of erosion, others are characterized by a high rate of accretion or both erosive and accretive laden processes. This accretion and erosion processes leave their influence on coastlines as landforms either of deposition or erosion origin. Landforms are conspicuous features of the Earth and occur everywhere and they range in size from molehills to mountains to major tectonic plates, and their 'life spans' range from days to millennia to aeons [8]. Studies [12] expounded coastal landforms as any relief feature present along the coastal areas that are produced by the combination of processes, sediments, and the geology of the coastal area where the landforms are found. Coastal land forms occur in the dynamic zone at the interface between the three major natural systems of the Earth's surface: atmosphere, ocean and land surface [3]. These landforms are susceptible to change when it is attacked by waves, coastal currents, the wind, sediment transport and anthropogenic activities [13]. "Studies [10] pointed out that depositional landforms manifest as beach, sandbar, sand spit, tombolo, coastal dune, offshore bar while the coastal erosional landforms are cliff, caves, blowhole, geo, notch, stack, arch, stumps." Some coastlines have changed little over the past 6000 years, most have advanced or retreated, and some have shown alternations of advance and retreat [14]. According to [5] Sea Cliffs are formed by undercutting work undertaken by sea waves leading to eventual collapse. The work of undercutting is subject to factors such as nature, structure and types of rock, resistance of rock to erosion, and presence of cracks, joints and other weaknesses in the rocks. They are mostly massive and dominate the coastline where it is found. One key importance of the cliff is that it provides habitat for plants and animals [15]. Further coastal processes lead to the formation of the Caves at the bottom of the cliff. A sea cave is formed predominantly because of the action of the waves. The prime process involved in the creation of Sea Caves is erosion where sea waves attack areas of softness in the coastal cliffs [5]. The diameter of a cave decreases from the entrance [9]. Waves and Sub-aerial processes combine to create a blowhole. If there is a joint from the roof of the cave to the top of the cliff, this becomes enlarged through the alternate expansion and compression of air in it, and in time a passage is opened, and if this reaches the top of the cliff it produces a blowhole [9]-[16].Further subsidence of divide between the blowhole and the cave develops an inlet that is geomorphologically termed a geo [16]. Due to the unending influence of waves, headlands are eroded on either side to create an arch, further action of the waves, either through hydraulic action, abrasion, attrition or solution, the rock roof of the arch collapses to form to create an inlet separating the main block from the remnant of block onshore called a stack. Since erosion is a continual process, these features are not permanent and will eventually be eroded, leaving no trace of their existence [17].

Traversing global coastlines, the most common coastal depositional landform is a beach [8]. It is a cover of wavedeposited sand or gravel over rock or a pre-existing sediment backshore. The gentle surging breakers move sediment up the shore to build a beach [10]. Coastal depositional processes form the beach, sand bar, tombolo, sand dunes and others. The beach is however the most extensive coastal depositional landform found along the coast. Reference [18] for instance in a touristic study of the coastline of Komenda averred that the beach is extensive. The beach is mostly found within the range of high tide and low tide. Its boundary onshore is determined by the margin of the shoreline. The beach extends from the low-tide line to the distinct change in slope and/or material landward of the unvegetated and active zone of sediment accumulation [17]. The materials that make up a beach can be an accumulation of sand or biogenous materials.

In Ghana, the $550 \mathrm{~km}$ stretch of coastline [19] is under constant change. Recently, the shoreline at Komenda which lies along the central coastal plain of Ghana is subject to accretion and erosional processes through shoreline change analysis conducted along Cape Coast to Sekondi coastline [19]. This is an indication that the shoreline which is partly rocky and sandy has been buffeted by different coastal depositional and erosional processes. Despite evidence of deposition and erosion processes along the shoreline, the spotlight of coastal research has not brought much attention to coastal landforms along the area. Studies have been conducted along the Komenda coastline, notwithstanding, these studies have not paramount the potential erosional and depositional forms. The only few studies that discussed coastal landforms in Ghana is the work of Dei, however, it was a general overview of the coastal landforms in Ghana $\mathrm{p}$. 944 [20]. More closely to the study area is the work of [18], which looked at some of the landforms at the Gold Hill 
beach but it did not focus attention on the forces that operate on the coastal landforms. Coastal geomorphological research in Ghana has given little attention to landforms resulting from erosion and deposition processes along the coastline of which the shoreline at Komenda is not immune from. More also, coastal processes within the Komenda shoreline have not been discussed in relation to the existing landforms. The study sought to identify landforms caused by erosional and depositional processes along the Komenda coastline and examined the possible factors that affect the rate of landform change.

\section{CONCEPTUAL FRAMEWORK}

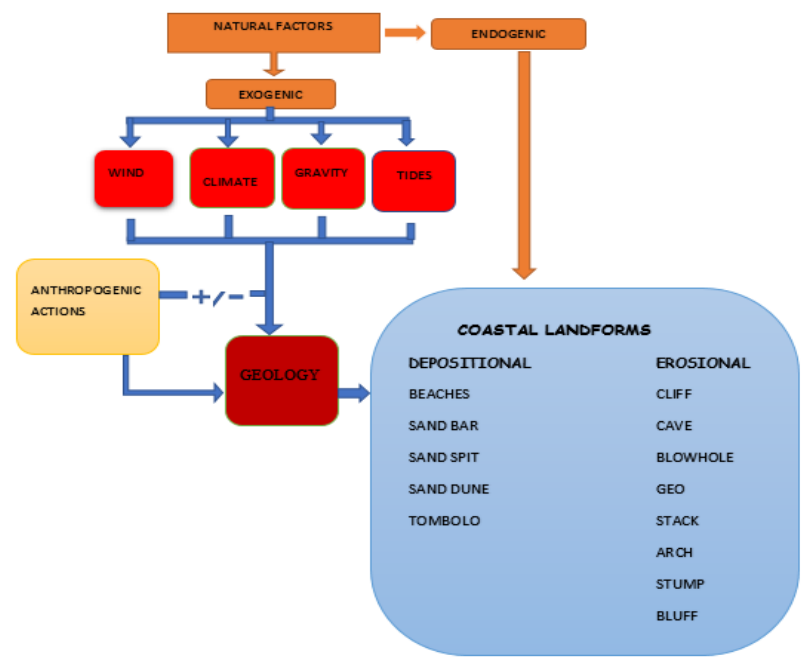

Fig. 1. Conceptual framework of coastal landforms Source: Author's construct

Fig. 1 illustrates the conceptual framework on which the paper was grounded. The coastal environment is believed to have been influenced by both natural and anthropogenic factors. These two factors operate simultaneously or in tandem to shape the coastal environment. The natural factors are of both endogenic and exogenic origin depending on where the force of the process will be initiated. The endogenic processes can directly lead to the formation of some coastal forms through tectonic upliftment. Exogenically, wind, climate action, gravity, and tides can also initiate the process of change. The product of wind is storm surge and waves while tides spring forth currents. Climate also induces forces such as rainfall and temperature change which can lead to a long-term rise or fall in sea level and sub-aerial activities. Gravity causes the fall of rocks or materials from a higher elevation to the base thereby speeding up sub-aerial activities such as weathering. These processes can be influenced by human actions or independently shape morphology. These processes culminate to accretion and or erosion. In some cases, anthropogenic actions can react with the natural factors to produce coastal landforms or act independently on the form. Some of the human actions at the shore, offshore or within a river catchment that is being discharged into the sea. These actions manifest in the form of mining at the shore or within rivers that are discharged into the sea, dams and coastal infrastructure that leads to either accretion or deposition. On the form, the geology of the coast determines whether it will be resistant or less resistant to human action and endogenic processes. The product of the process-form relationship leads to the formation of coastal landforms either of erosion or deposition origin. By this, human beings, in turn, benefit from the landforms either socially, economically or culturally. The paper was guided by the following research questions: (i) To identify the coastal depositional and erosional landforms along the Komenda coastline; (ii) To ascertain the possible factors influencing the coastline.

\section{Methodology}

\section{A. Study Site}

The study area is the shoreline along Komenda (Gold Hill) behind the Komenda College of Education found in the Komenda Edina Eguafo Abirem Municipality in the central region of Ghana. The Coastline understudy is approximately $1 \mathrm{~km}$ and geographically located at Lat 5o3'23.95 N/Long 1028 '2.23" W (Komenda). This area has an equatorial climate, characterized by wet and dry seasons, and is influenced by the southwest monsoon winds [21]. It experiences a lower level of rainfall with double maxima rainfall, annual rainfall total ranges between $750 \mathrm{~mm}$ and $1,000 \mathrm{~mm}$ [22]. Temperatures are generally high at Komenda. Geologically, the shoreline is largely comprised of Sekondi sandstone [23]. For the purposes of discussion, the coastline was divided into three (3) sections i.e. I, II, III based on the factors influencing the coast and the degree of dominance. Part I is dominated solely by sub-aerial processes, II both sub-aerial processes and waves and III is moderately buffeted by wave action.

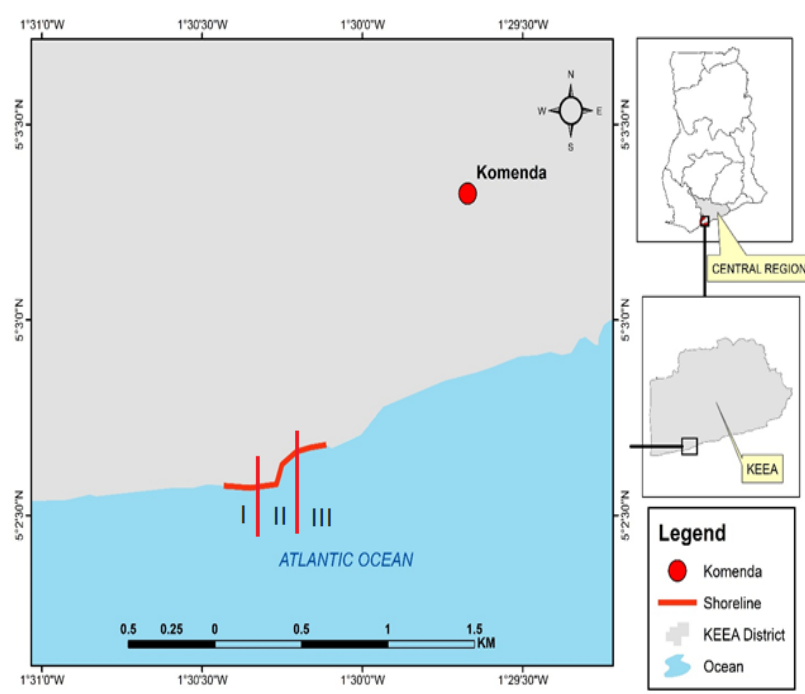

Fig. 2. Map of the study area in regional and national context. Source: Authors' construct.

\section{B. Research design}

The study employed a descriptive study research design. This is because the research sought to observe and give a detailed description of landforms at the study site of Komenda without influencing it. Descriptive research is thus a scientific method of observing and describing the behaviour of nature or a subject without tampering with its originality [24]. The study also thrived on both quantitative and qualitative information. The quantitative information provided an insight into the height, width and length of the 
respective landforms and the qualitative aspect has to do with the description of the landforms in terms of shape and its manifestation.

\section{Data types}

The paper used both spatial and non-spatial techniques to arrive at the findings. Spatial data include the vector country shapefiles of Ghana. Also, the geographic coordinates of the study were obtained with Mobile Phone GPS. Among the non-spatial data collected were the photographic images and on-site measurement of landform height and width that were taken and the observation of the factors operating within the environment encapsulating the primary source of data collected.

\section{Sampling and sampling technique}

The study sampled the entire coastal stretch influenced by erosion and deposition along the Komenda shoreline. These include the sandy beach, the geo, the blowhole, the stack, the caves and stumps.

Purposive sampling technique was adopted by the researchers to identify the landforms caused by both deposition and erosional processes along the Komenda shoreline. We used the Purposive sampling technique to choose data (landforms) that is in line with the objectives of the research. In this vein, [25] strengthened the need for the use of purposive sampling that "purposeful sampling helps the researcher to choose data that fit the parameters of the project's research, questions, goals, and purposes.

\section{E. Data Collection}

In October 2018, a reconnaissance survey was conducted to give the researchers much information about the nature of the shoreline. In this period, we identified some of the landforms and observed the processes that are operating within the coastal environment and shaping the coastline. Following the reconnaissance survey, we collected the actual data in December 2019. The choices of different times and such dates for data collection were influenced by the willingness to experience the shoreline in different seasons. This gave a good picture of the forces in operation at the coastal environment in these different seasons. The researchers measured the height and width of the landforms with the use of measuring tape. The results of the measurements were presented in a tabular form. 'My Tracks' (Android Phone GPS APP) was also used to measure long distances along the shoreline (length of the shoreline); while 'My Tracks' were opened and activated on the smartphone, we moved from part I to III of the coastline. 'My Tracks' was also used to measure the length of the caves. The purpose of its usage in this wise was to validate and support the measurements obtained through the Measuring Tape. The length of the distance covered from Part I to III of the coastline was recorded by the App. The researchers also used Google Earth to measure the total approximate lengths of the shoreline. The data from Google Earth helped us to ascertain the veritable distance of the coastline and create the locational map of the study coastline. In Google Earth, the length of the shoreline was digitized and saved as a Keyhole Markup Language (KML) file. It was imported into ArcMap and converted into ESRI shapefile (shp.) with the conversion tool in the ArcTool Box, this made it usable for the creation of the locational map.
The researchers used ArcMap 10.5 to create the map of the study area with the combined data from Google Earth and the Vector Country shapefile of Ghana obtained from the Department of Geography Education. A digital camera was then used to capture all the landforms and the processes observed. The instruments that were used to collect data (information) are observation to take note of the changes occurring on the landforms were digital camera to take pictures of the landforms, Mobile phone GPS device to obtain the geographic coordinate of the area, Pictorial view of the landforms was used to present the results in thematic form.

\section{F. Roundness and flatness values analysis}

To examine the extent of erosion and deposition at the study area there was measurement and determination of shapes to understand the impact of sea erosion on the morphology and the lithological environments. The intensity of sea erosion and sedimentation can be determined by the size and degree of roundness and flatness of pebbles. In this regard, the indices of [26] for analysing pebbles were employed due to its reliability, simplicity and easier interpretation.

Thus, during the field work, 65 pebbles of sandstone (iron stone) were collected from Komenda for laboratory analysis. The formulae used for roundness and flatness (Cailleaux Indices) are shown below:

$$
\text { Roundness Index } \mathrm{R}=\sqrt{\left(\frac{2 r}{L}\right)(1000)}
$$

Where $\mathrm{R}$ is the roundness of pebbles, $\mathrm{r}$ is the radius of the smallest curvature of pebbles; $\mathrm{L}$ is the diameter or length of pebbles.

$$
\text { Flatness Index: } F=\sqrt{\frac{L+b}{2 E}}
$$

Where $\mathrm{F}$ is the flatness of the pebble, $\mathrm{L}$ is the length, $\mathrm{b}$ is the breadth and $E$ is the thickness of pebbles [27]. Thus, based on the formulae stated above, the length of pebbles, breadth, smallest curvature, flatness and other dimensions were measured with the help of a digital caliper.

\section{G. Presentation of results}

The results of the research were presented through a thematic discussion of coastal landforms caused by deposition and erosion. The discussions were buttressed with photographic presentations. Also, the possible factors that shape the coastline were as well discussed thematically and supported with photographic presentations. In order to rightly communicate the quantitative components of the landforms, the height and width of some landforms were displayed with a table.

\section{Results And Discussion}

\section{A. Coastal depositional landforms identified}

The study revealed an extensive sandy beach overlapping the western part of the cliff and extending far west of the Komenda coastline with length more than 100 meters wide. 
This finding affirms [18] that there is an extensive sandy beach at the Komenda shoreline. The sandy beach at Part I have a few meters upraised. This affirms [19] assertion that part of the beach at Komenda is upraised. More also, the sandy beach is formed from the selective deposition of sandy materials at the shore. Most recreational activities occur on this Sandy beach site. Nearing the cliff at the eastern section, the sandy beach translates to the rocky beaches. Geomorphologically, the beach lies at the backshore extending into the foreshore where there is an unpredictable shift in the shoreline.
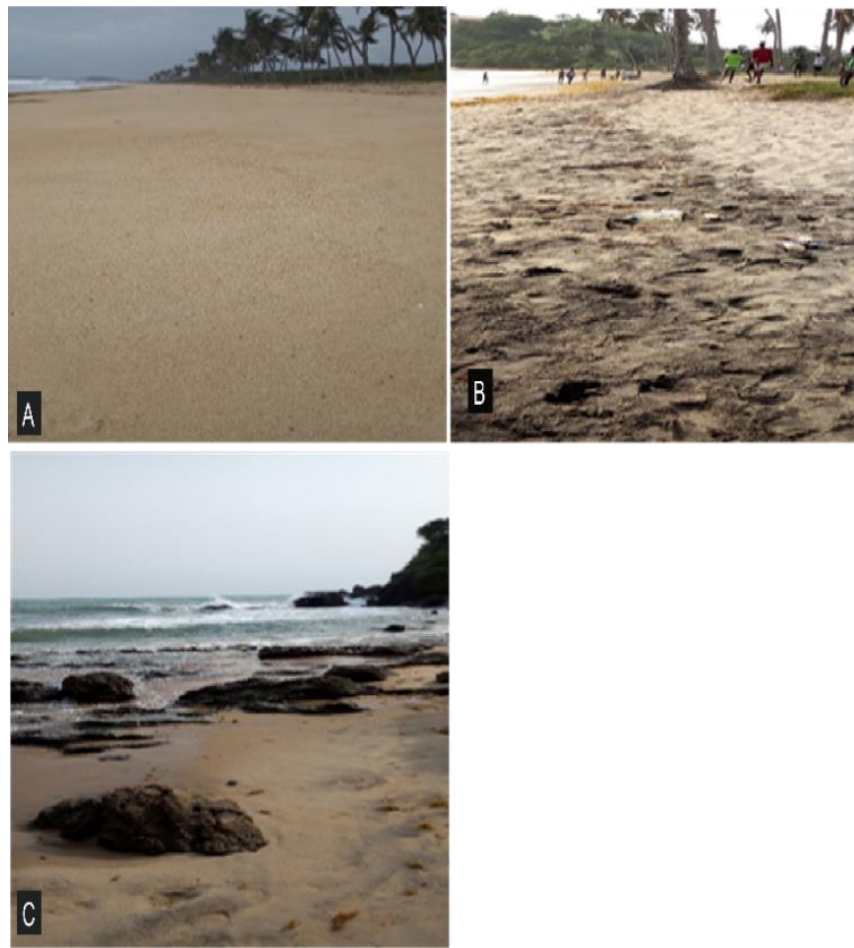

Plate 1:(A) Sandy beach in the Western (I) part of the shoreline. (B) Sandy beach and at the Eastern part (III); (C) Rocky coast all at the Eastern part (III) of the coast. Source: Fieldwork, (2019).

\section{B. Coastal erosional landforms identified}

A wide range of coastal erosional landforms were discovered along the Komenda coastline. Among them were;

Coastal cliff: the predominant coastal erosional landform is the coastal cliff extending from part I to III of the study shoreline. The study revealed that the cliff represents escarpments that mark abrupt changes in slope, formed by marine erosion and covered with vegetation. This observation aligns with [20] assertion that the cliff is covered with vegetation. The observation of vegetation on the cliff confirms [15] assertion that the cliff serves as a habitat for plants. The cliff generally consists of a rocky substrate and appears to be very high. The study revealed that seawater does not influence it anymore and hence any change observed in the cliff may be caused by sub-aerial processes (Mass wasting and Weathering). Inferably, endogenic forces such as Diastrophism might be responsible factor for any major displacement of the cliff in the future since the waves do not establish contact with a large part of it.

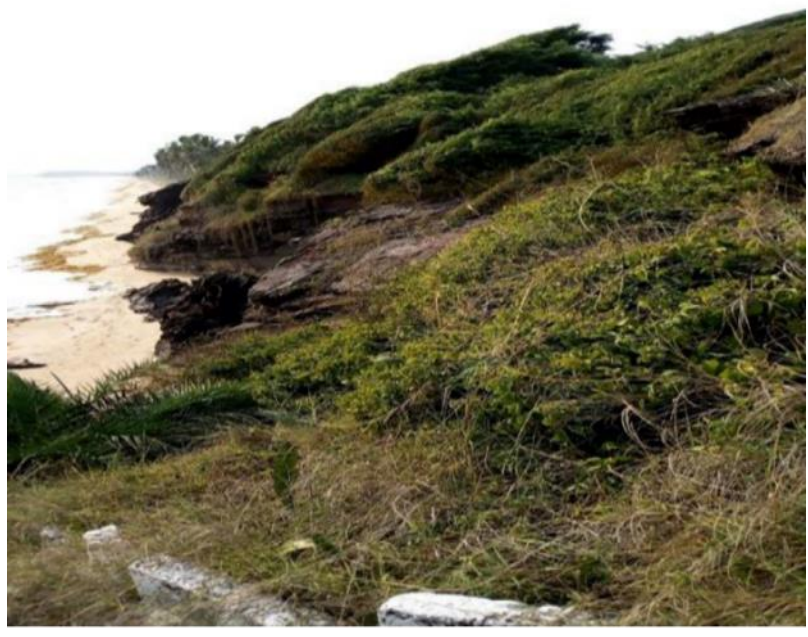

Plate 2: Coastal cliff

Source Fieldwork, (2019)

Cave: Next to the cliff in terms of predominance is the coastal cave. The study revealed four (4) different caves ranging from part I to III of the Komenda coastline. At part I, cave IV was found and it narrows from the entrance towards the inside. Authors [9] puts it as 'the diameter of a cave decrease from the entrance'. Cave IV has the potential of developing a blowhole in the future when subjected to further sub-aerial processes [9]. At part II of the coastline, the researchers identified cave I adjoined to the geo at its east. Passage through the cave I is possible which leads to the geo. Cave III was also identified in the central part of the coastline and its width decreases from the entrance towards the inside. Also, we identified Cave II at Part II of the coastline. Passage through Cave II is possible, and it heads toward the base of a blowhole. It must be accentuated that a cave, a blowhole and geo are neighbouring coastal landforms by virtue of the sequentially linked processes of their formation. Generally, there weren't any observed changes in the caves from the period where the reconnaissance survey took place until the actual period of data collection, except for cave III which there was an observed change in the accumulation of sand. This is because the waves are not influencing the rest of the caves. This support [5] assertion that the erosion (waves) is the prime force that affects the cave.

Geo: The study also revealed a geo is adjoined to cave II at its west within the central part of the coastline [9]. From the findings of the study, the geo was formed through a former process of both sea waves and climate. This affirms the postulation of the framework of coastal landforms Fig. 1 that the combined action of waves and climate reacts with the geology to produce geo. Considering the extent of the shoreline now, the geo is no more under the influence of the sea waves; however, it is still influenced by sub-aerial processes sterned from gravity. 

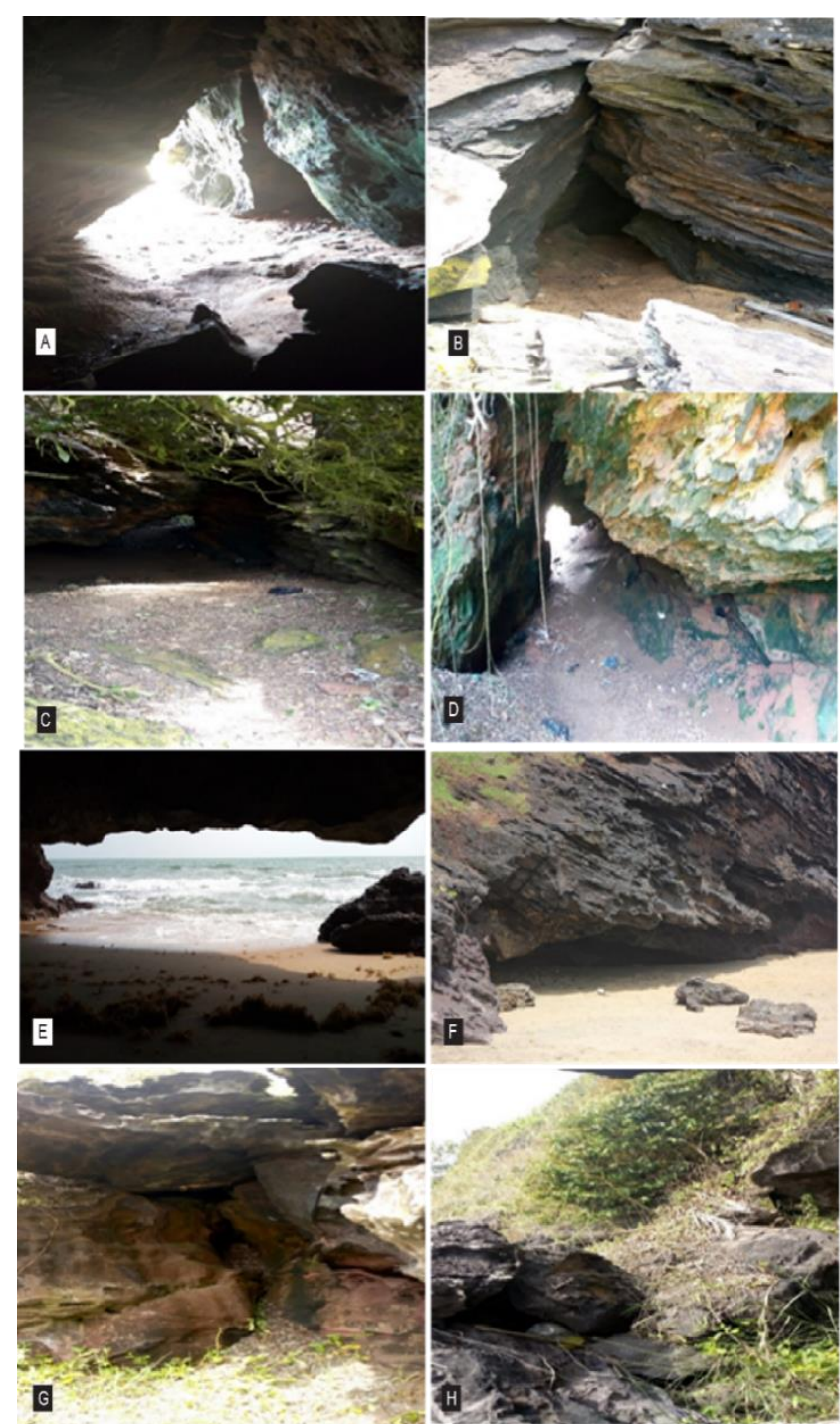

Plate 3: AB: Cave I, CD: Cave II, EF: Cave III, GH: Cave IV. Source: Fieldwork, (2019)

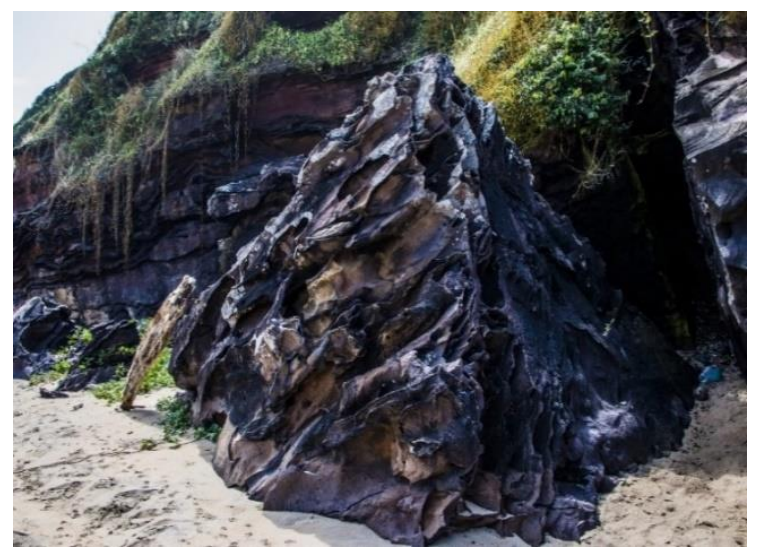

Plate 4: Geo Source: Fieldwork, (2019).

Blowhole: We also identified a blowhole at the Part (II) of the coast. Passage through Cave III leads to the Blowhole; hence it is found at the roof of Cave III [9]-[16]. Also, the blowhole is cylindrical in nature. This affirms [16] claim that a blowhole is a cylindrical shaped feature that develops and extends from the roof of the cave to the top of the cliff during wave attack. The researchers found the top of the blowhole vegetated. The distance from the blowhole to the entrance of the cave is about 1 meter [20].

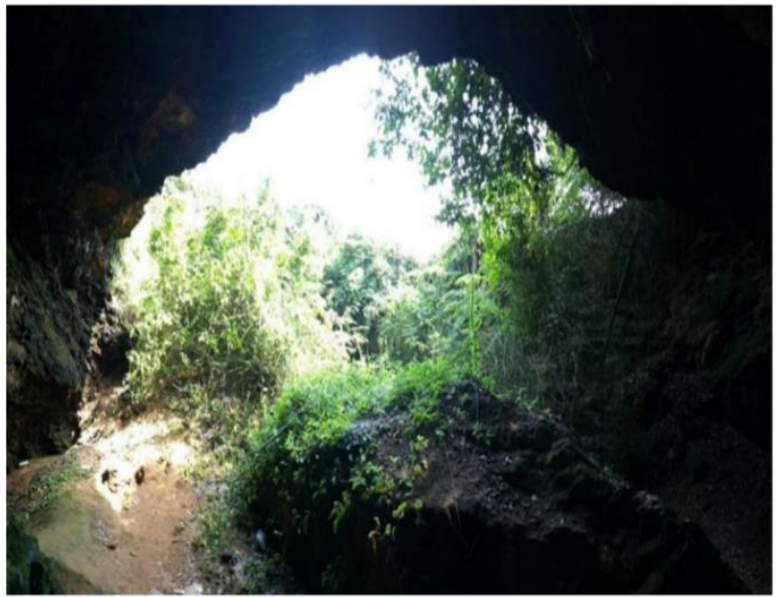

Plate 5: Blowhole. Source: Fieldwork, (2019).

Stack: The study revealed a high standing stack about a few meters offshore. The stack is steep-sided [16]. The stack is constantly under the influence of destructive wave attack due to aggravation of storm surge that intensifies coastal erosion in seasons of high tide. The permanency of the stack is not assured since the waves may erode it until it disappears [17]. This agrees with the assertion in Fig. 1, that tides affect the local geology to produce stack.

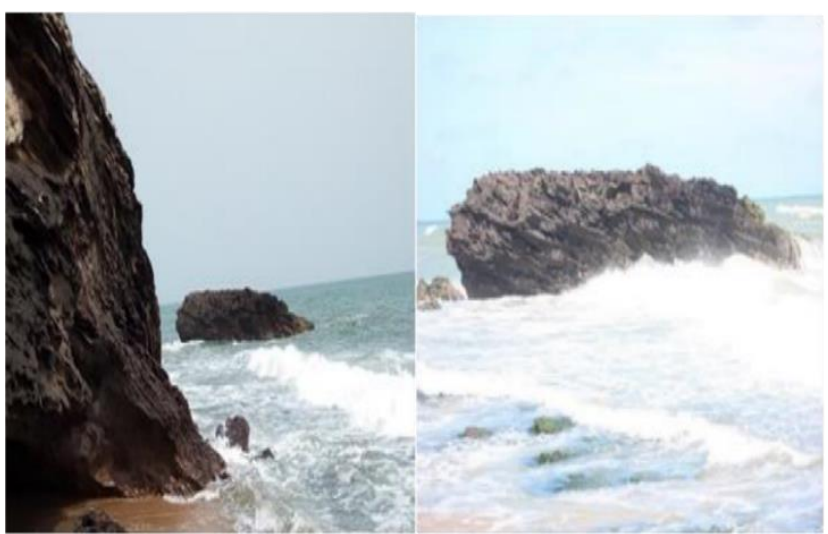

Plate 6: Stack. Source: Fieldwork, (2019).

Stump: The study revealed stumps in which few of them are a little above normal sea level. It is apparent they were hitherto Stacks that have undergone years of wave erosion resulting in now Stumps [16]. This finding, therefore, affirms the fact that waves affect the geology of the coast to produce stumps as espoused in the conceptual framework Fig. 1. Some of the stumps have algae on them. Most of the stumps are submerged during low tides.

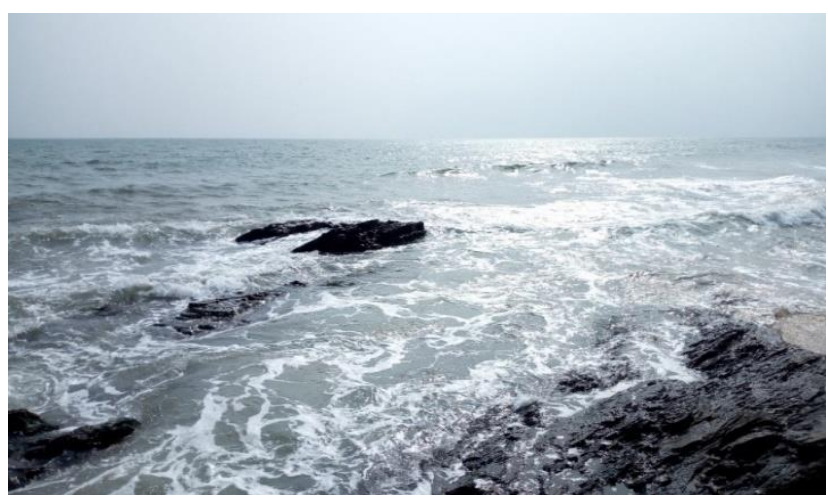

Plate 7: Stump. Source: Fieldwork, (2019). 
TABLE I: MEASUREMENTS OF THE COASTAL EROSIONAL LANDFORMS

\begin{tabular}{llll}
\hline \hline Landforms & Height (meters) & $\begin{array}{l}\text { Width }(\mathbf{m} / \mathbf{k m}) \\
\text { (Description) }\end{array}$ \\
\hline Cliff & I & 15.8 & $1 \mathrm{~km}$ \\
\hline \multirow{3}{*}{ Cave } & - & $\begin{array}{l}0.6 \mathrm{~m} \text { at the } \\
\text { entrance; extends to } \\
1.03 \mathrm{~m}\end{array}$ \\
\cline { 2 - 4 } & II & 2.07 & $\begin{array}{l}2.43 \mathrm{~m} \text { at the } \\
\text { entrance; extends }\end{array}$ \\
& & & $6.4 \mathrm{~m}$ \\
\cline { 2 - 4 } & III & - & $6 \mathrm{~m}$ at the entrance \\
\cline { 2 - 4 } & IV & - & $\begin{array}{l}2.46 \mathrm{~m} \text { at the } \\
\text { entrance; narrows } \\
\text { to } 0.03 \mathrm{~m}\end{array}$ \\
& & $\begin{array}{l}1.2 \mathrm{~m} \text { entrance; } \\
\text { narrows } 0.6 \mathrm{~m}\end{array}$ \\
\hline Geo & 5.79 & $4.57 \mathrm{~m}$ in diameter \\
\hline Blowhole & 15 & $\begin{array}{l}4 \mathrm{~m} \text { (Distance from } \\
\text { the main cliff }\end{array}$ \\
\hline Stack & 2.64 &
\end{tabular}

Source: Fieldwork, (2019).

Table I reveals that cliff as highest landform with a height of 15.8 meters and the longest with a width of about $1 \mathrm{~km}$. Another geomorphic feature that had its height closely ranked to the cliff is the blowhole a depression at the top of the cave. It was observed that distance from the entrance of the cave inwardly narrows.

\section{Intensity of waves and extent of sea erosion (Roundness and Flatness Index/Values)}

A Cailleux index was employed to calculate the roundness and flatness values in the study area. The application of this methodology gives a comprehensive knowledge about the rate and extent of wave and erosion action in the area.

TABLE II: ROUNDNESS INDEX FOR STUDY AREA (SEKONDI SANDSTONE)

\begin{tabular}{llll}
\hline Description & Range $(\mathbf{m m})$ & Frequency & Percent \\
\hline Less round & Up to 500 & 5 & 8 \\
Moderately round & $501-1000$ & 38 & 59 \\
Extremely round & Above 1000 & 22 & 34 \\
\hline Total & & 65 & 100 \\
\hline
\end{tabular}

Source: Field data (2019).

Table II revealed only (5) $8 \%$ of the sampled pebbles were found to be less rounded. About 60 (93\%) of the pebbles were found to be moderately to extremely flat.

TABLE III: FLATNESS INDEX FOR STUDY AREA (SEKONDI SANDSTONE)

\begin{tabular}{llll}
\hline \hline Description & $\begin{array}{l}\text { Range } \\
(\mathbf{m m})\end{array}$ & Frequency & Percent \\
\hline Less flat & Up to 2 & 16 & 25 \\
Moderately flat & $2.1-3.0$ & 37 & 57 \\
Extremely flat & Above 3 & 12 & 18 \\
\hline Total & & 65 & 100 \\
\hline Source: Field data (2019). & &
\end{tabular}

Table III revealed that (16)25\% of pebbles were discovered to be less flat while (37) $57 \%$ is moderately flat with (12) $18 \%$ extremely flat. Though roundness values were higher for moderate and extremely round, indicating intense erosion, the flatness values were more of moderately flat yet as high as $75 \%$ of sampled pebbles were found to be moderately to extremely flat. There is an exposition of intense erosion at Komenda shoreline and support the view expressed by [28].

\section{Possible factors affecting the rate of landform change}

Weathering: The study revealed that part I of the study area was once under the influence of wave action and now it is grossly affected by rainwater. This has led to the process of oxidation which is a chemical weathering process as espoused by [16]. This has turned the landscape of the area into a reddish-brown colour of the rocks. Rainwater leading to oxidation is found within the climate category of the conceptual framework (Fig. 1) of the study. Hence, it confirms the postulation of the conceptual framework. The study also revealed the burrowing action of animals on the oxidized rock. This is having created pore spaces in the rock and the existence screes at the base of the weathered rocks. Screes are soil-like products which are the product of the oxidation process along the face of the cliff.

The study also revealed the existence of granular disintegration and block disintegration at parts I and III of the study area respectively. Granules are caused by the dominance of climatic influence [16] which sterns from exogenic forces that shape the geology [8]. The cause of the granules is in sync with the conceptual framework (Fig. 1) of the study in part I of the coast. The study showed a group of collapsed blocks (Block disintegration) found in part III of the Komenda coastline. The seawater does not establish contact with the top of the cliff, yet, there was a recent collapse of the rock. This indicated the operation of subaerial processes like weathering (Block disintegration). The Sub aerial processes (climate reacting with a susceptible rock) that led to the disintegration of blocks are in sync with the propositions in the conceptual framework in Fig. 1 and [8]. The disintegration process stems from the combination of gravity and influence of climate on the geology.

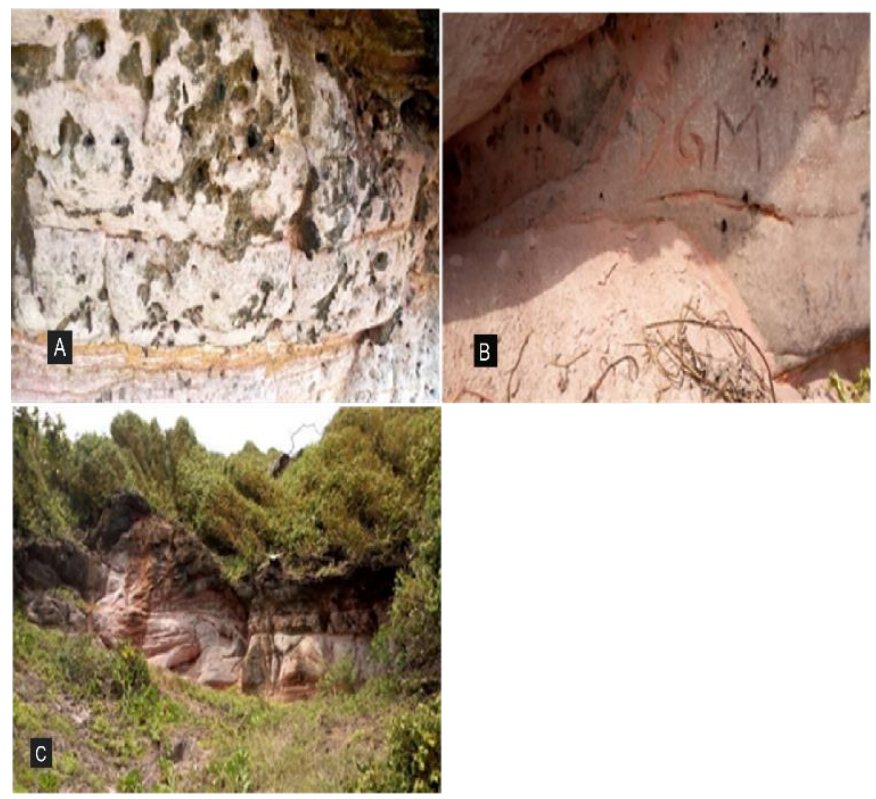

Plate 8:(A) Burrowing action. (B) Screes (C) Oxidation of rocks through chemical weathering. Source: Fieldwork, (2019). 


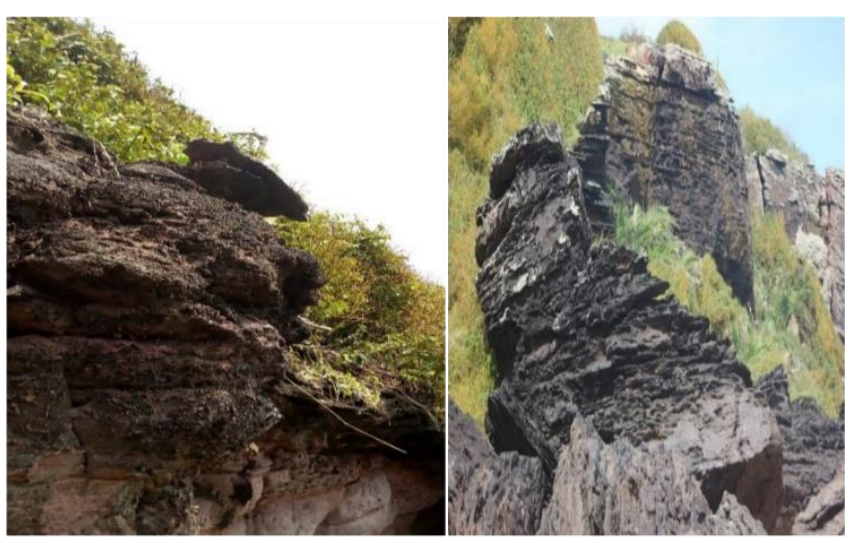

Plate 9: Granular and Block disintegration. Source: Fieldwork, (2019).

Mass Wasting:The study revealed massive rockfall at the cliff face thereby creating an inlet on the eastern (Part I) aspect of the coastal cliff. This collapsed part of the cliff has been buried by screes generated from weathering processes. The remnant block with an inlet is a bluff that is now vegetated. This finding aligns with [20] report that behind the beach and to the east of the cave are bluffs almost completely covered by vegetation. They were former cliffs, degraded by subaerial processes after emergence. The formation of the bluff is also in consonance with the conceptual framework Fig. 1 where the combined action of climate and Gravity (manifests as mass wasting) reacts with Geology to produce landforms.
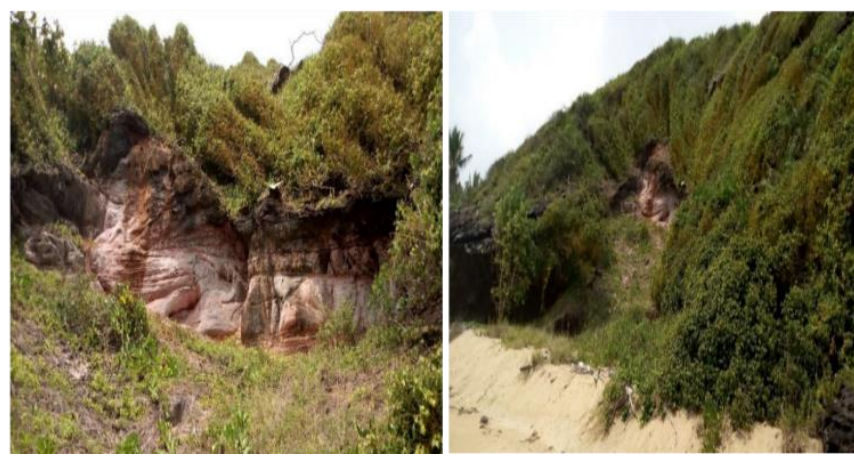

Plate 10: Evidence of rock fall creating a bluff at Part I of the shoreline. Source: Fieldwork, (2019).

Wave Action: The study showed that the predominant factor affecting landform change in part I of the coastline is the impact of sub-aerial processes (weathering and mass wasting). 'Reference [8] asserted that sub-aerial processes affect landform change.' The influence of wave at part I of the coastline is rare and hence, the seawater does not establish contact with the cliff even in seasons where there is a rise in the level of the seawater [19]. In December, a section of part II of the Komenda coastline is greatly influenced by the wave action. During this period, the swash hit the rock with strong force causing erosion. The study also showed the growth of green algae on the stumps part II of the coastline. Their growth is facilitated by the sporadic influence of the swash and backwash on the rocks. The study revealed that part III of the coast is predominated by wave action. This is evident in the ever-constant interaction between the seawater and the stack and the petrification of an elongated wood.
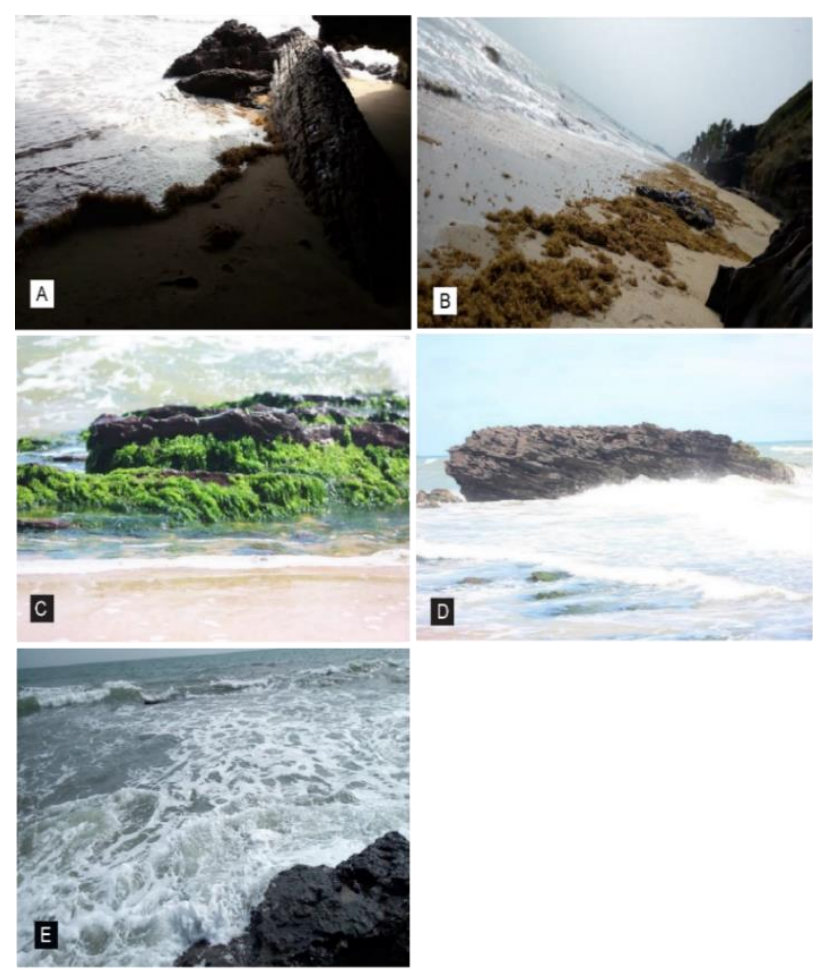

Plate 11: Evidence of wave action; (A) Petrified wood; (B) Seaweed as evidence of shoreline advancement (C) Green algae (D) Stack under wave attack (E) Submerged stumps. Source: Fieldwork, (2019).

\section{CONCLUSION AND ReCOMmEndations}

The paper concludes that coastal erosional landforms are predominant along the coastline than depositional landforms with the erosional landforms comprising cliff, bluff, geo, blowhole, caves, stack and stump. The Sea Caves identified were four with only Cave III still buffeted by wave action. Within the cave is a petrified wood that is still in the process of transformation into stone. The coastal cliff is the most extensive of all the individual coastal landforms; the cliff is extensively covered with vegetation. The only coastal depositional landform identified is an extensive sandy beach of which portion are raised at part I and an alternating rocky at part III of the coastline. Sub-aerial processes such as weathering (physical and chemical) and mass wasting are the major factors affecting part I of the coastline and hence the waves do not come into contact with the coastal cliff at this part of the coastline. On the cliff, the sub-aerial processes such as rain and temperature have contributed to the growth of the vegetation. Also, in section II of the coast, the sub-aerial processes are inferably the cause of the collapse of the blocks. Coastal landforms along the coastline are a product of the interaction between wave actions and sub-aerial processes with the local geology responding to these geomorphic processes. Finally, the Komenda coastline is still under the influence of wave action but not the dominant force affecting the coastal landforms. It must be stated that sub-aerial processes are instead the dominant factor influencing the landforms since the waves rarely make contact with the cliff, geo, blowhole, caves (except Cave III). Notwithstanding, the distance between the shoreline at high tide and the coastal landforms are not wide. Hence, a rise in sea level can revive the influence of wave action on the coastal landforms along the Komenda coastline. 
From the observation on the Komenda coastline, a graphical model has been built to define the processes shaping the existing landforms as:

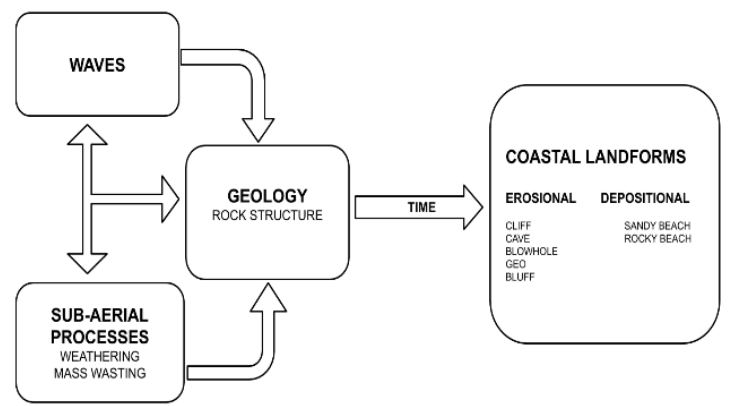

Fig. 3. Model on the formation of Coastal Landforms. Source: Authors' Construct.

From Fig. 3, landform reflects the resistance ability of the geology to the combined/independent action of waves and sub-aerial processes through time.

Based on the findings, the researchers made the following recommendations:

1. The study recommended the adoption of the study area as a research site by the Ghana Geographers Association to intensify research on coastal landforms in Ghana.

2. The study recommended that it is necessary to increase research in the study area by Universities in Ghana for a comprehensive understanding of its climatic, hydrodynamical, geological and geomorphological conditions, among others, which will provide a more and better understanding of the factors shaping the coastline at every point in time.

3. Moreover, as policy implication, the study recommended that the Ministry of Tourism should adopt the area as a Geo-tourist centre to boost the economic importance of Ghana's coastal resources and also ensure the sustainable conservation of the area.

\section{ACKNOWLEDGMENT}

The authors acknowledge the support received from the Department of Geography Education in the form of logistics used in travelling to the study site several times and the development of the study area map.

\section{REFERENCES}

[1] A. Anderson, U. Ratas, R. Rivis, and V. Palginõmm, (2012) Relationship between coastline changes and dynamics of coastal ecosystems of Tahkuna Peninsula, Estonia. IEEE/OES Baltic International Symposium (BALTIC), Klaipeda, 2012 [online]. pp. 16. Available: doi: 10.1109/BALTIC.2012.6249189

[2] S. Kurt, A. Karaburun, and A. Demirci, "Coastline changes in Istanbul between 1987 and 2007," Scientific Research and Essays, vol 5, no. 19 , pp. $3009-3017,2010$

[3] R. Davidson-Arnott, Introduction to coastal processes and geomorphology, 2010.2 [online]. Available: www.cambridge.org/9780521874458

[4] J. F. Petersen, D. Sack, and R. E. Gabler, Fundamentals of physical geography, Belmont: Brooks/Cole, Cengage learning, 2011.

[5] F. M. Nadaf, "Geographical analysis of the coastal landforms of Canacona, Goa," Research Review International Journal of Multidisciplinary, vol. 4, no. 2, pp. 655-661, February 2019.

[6] D. Mottershead, (2013). "Coastal weathering," In Treatise on geomorphology, Vol. 4, J. F. Shroder, and G. A. Pope, Eds. San Diego: Academic Press, 2013, pp. 228-244.

[7] B. D. Angnuureng, K. Appeaning Addo, and G. Wiafe, "Impact of sea defense structures on downdrift coasts: The case of Keta in Ghana,"
Academia Journal of Environmental Sciences, vol 1, no. 6, pp. 104121, 2013.

[8] R. J. Hugget,Fundamentals of geomorphology, 3rd ed. New York: Routledge, 2011

[9] R. B. Bunnett and P. O. Okunrotifa, General geography in diagrams for West Africa, China: Longman Group Limited, 2005.

[10] A. Gupta, Tropical geomorphology, New York: Cambridge University Press, 2011

[11] S.J. Williams, "Sea-level rise implications for coastal regions," in Understanding and predicting change in the coastal ecosystems of the northern Gulf of México, eds. J.C. Brock, J.A. Barras, S.J. Williams, Journal of Coastal Research. Special Issue, 2013, 63:184-196.

[12] R.A. Davis, Coastal Sedimentary Environments, New York: Springer Science \& Business Media, 2012

[13] F. Yulianto, T. Suwarsono, Maulana, and M. R. Khomarudin, (2019). Analysis of the dynamics of coastal landform change based on the integration of remote sensing and gis techniques: Implications for tidal flooding impact in pekalongan, central java, Indonesia. Quaestiones Geographicae [online]. 38(3). pp. 17-29. Available: https://doi.org/10.2478/quageo-2019-0025

[14] E. Bird, Coastal geomorphology: An introduction, 2nd ed. Chichester: John Wiley \& Sons, Ltd., 2008

[15] A. P. Young, and J. E. Carilli, (2019). Global distribution of coastal cliffs. Earth Surface Processes and Landforms [online]. 44(6), 13091316. Available: https://doi.org/10.1002/esp.4574

[16] I. Y. Dadson, K. Adu-Boahen, and A. B. Owusu, Essentials of physical geography, Cape Coast: UCC Press, 2015.

[17] R. A. Davis, (September, 2018). Coastal landforms. EncyclopaediaBritannica,Inc

[online].Available:https://www.britannica.com/science/coastallandform

[18] R. K. Acquah and D. O. Appiah, "Coastal dynamics and touristic potentials in Ghana: A geomorphicalstudy,"presented at the GGA/GGTA conference, University of Education, Winneba, August $5-8,2018$

[19] I. Y. Dadson, A. B. Owusu, and A. Osman. (2016). Analysis of shoreline change along Cape Coast-Sekondi coast, Ghana. Geography Journal [online]. Available: https://doi.org/10.1155/2016/1868936

[20] L. A. Dei, "Ghana," In Encyclopedia of the world's coastal landforms, Vol. 1, E. C. F. Bird, Ed. Dordrecht: Springer, 2010.

[21] F. E. Jonah, E. A. Mensah, R. E. Edziyie, N. W. Agbo, and D. AdjeiBoateng. (2016). Coastal erosion in Ghana: Causes, policies, and management. Coastal Management [online]. 44(2). pp. 116-130. Available: https://doi.org/10.1080/08920753.2016.1135273

[22] Ghana Statistical Service (GSS), 2010 population and housing census District analytical report; Komenda-Edina-Eguafo-Abirem Municipal, Ghana Satistical Service, 2014

[23] I. Y. Dadson, K. Adu-Boahen, and B. K. Nyarko, "Morphological classification and protection of the central coastline: Implications for erosion management in Ghana."Social Science Journal, 2018 [online]. 2. Available: http://purkh.com/index.php/tosocial

[24] C. R. Kothari, Research methodology: Methods and techniques, 2nd Ed. New Delhi: New Age International Publishers Ltd, 2004.

[25] S. J. Tracy, Qualitative research methods: Collecting evidence, crafting analysis, communicating impact, Chichester: WileyBlackwell, 2013.

[26] A. Cailleaux, "Distinctions des galetsmarins et fluviatiles." Bulletin, Societe Geologique de France, vol 5, pp. 375-404, 1945.

[27] W.J. Krumbein and L.L. Sloss, Stratigraphy and sedimentation, 2nd Ed. San Francisco: W. H. Freeman and Company, 1963

[28] P.D. Komar, Beach processes and sedimentation, 2nd Ed. New Jersey: Prentice-Hall, Inc, 1998.

Kofi Adu-Boahen is the lead author and holds a Ph.D. in Geography and Regional Planning from the University of Cape Coast Ghana. He is Senior Lecturer at the University of Education, Winneba, Ghana.

Ishmael Yaw Dadson holds a Ph.D. in Geography from the University of Cape Coast Ghana. He is a Senior Lecturer at the University of Education, Winneba, Ghana.

Samuel Agyekum is a National Service person at the Department of Geography Education. He holds B.A Geography Education from the University of Education Winneba. 